\title{
Efektivitas Ekstrak Artemisia vulgaris L. sebagai Hepatoprotektor pada sel-sel Hati Tikus yang Diinduksi Niasin
}

\author{
(The Effectivity of Artemisia vulgaris L. Extract as a \\ Hepatoprotector in Rat Hepatocytes Induced by Niacin)
}

\author{
Laily Rahmawati, Erma Sulistyaningsih, Rosita Dewi \\ Fakultas Kedokteran Universitas Jember \\ Jln. Kalimantan 37, Jember 68121 \\ e-mail: sulistyaningsih.fk@unej.ac.id
}

\begin{abstract}
The niacin in energy drinks has metabolic product that cause oxidative stress and liver damage, while the liver damage can be prevented by hepatoprotective agents. Scoparone in Artemisia vulgaris L. can act as a hepatoprotector by its antioxidant effect. This study aimed to investigate the effectivity of Artemisia vulgaris L. extract as a hepatoprotector in wistar hepatocytes induced by niacin. This study used 25 male rats which were divided into 5 groups: normal, the negative control, the positive control, the treatment group I, and II. Treatment was conducted for 28 days. The samples were terminated and the hepatocyte were prepared for histological examination. Histological appearance was catagorized as mild, moderate, and severe damage with or without inflamatory cells activity. The data analysis by Kruskal Wallis showed significant difference $(p<0,001)$. Further analysis by Mann Whitney revealed significantly difference $(p<0,05)$ between normal group and all groups, negative control group and positive control group, and positive control group and treatment group I, but not significantly difference between negative control group and treatment group I, negative control group and treatment group II, positive control group and treatment group II, and between treatment groups. The study concluded that the effectivity of Artemisia vulgaris L. extract has not been proven as a hepatoprotector but further study is needed to draw a definite conclusion.
\end{abstract}

Keywords: energy drink, niacin, Artemisia vulgaris L., hepatoprotector

\begin{abstract}
Abstrak
Kandungan niasin dalam minuman berenergi memiliki hasil metabolik yang menyebabkan stres oksidatif dan kerusakan hati. Kerusakan hati dapat dicegah dengan bahan-bahan hepatoprotektor. Scoparone pada Artemisia vulgaris L. diduga dapat dimanfaatkan sebagai hepatoprotektor melalui sifat antioksidannya. Penelitian ini bertujuan mengetahui efektivitas ekstrak Artemisia vulgaris L. sebagai hepatoprotektor pada sel-sel hati tikus yang diinduksi niasin. Penelitian ini menggunakan 25 tikus wistar jantan, dibagi menjadi 5 kelompok penelitian, yaitu kelompok tanpa perlakuan $(\mathrm{KN})$, kontrol negatif $(\mathrm{K}-)$, kontrol positif $(\mathrm{K}+)$, perlakuan pertama (P1) dan kedua (P2). Setelah 28 hari perlakukan, hewan coba diterminasi dan dilakukan preparasi untuk pengamatan gambaran histopatologi yang dikategorikan sebagai kerusakan ringan, sedang, berat dengan ada atau tidak aktivitas sel-sel inflamatori. Analisis data menggunakan Kruskal Wallis didapatkan perbedaan bermakna $(p<0,001)$, uji lanjutan dengan Mann Whitney menunjukkan perbedaan bermakna $(p<0,05)$ antara KN dan semua kelompok; Kdan $\mathrm{K}+$; $\mathrm{K}+$ dan $\mathrm{P} 1$, tetapi tidak terdapat perbedaan bermakna antara $\mathrm{K}$ - dan $\mathrm{P} 1$; $\mathrm{K}$ - dan $\mathrm{P} 2$; $\mathrm{K}+$ dan P2; P1 dan P2. Dapat disimpulkan bahwa ekstrak Artemisia vulgaris $L$. belum terbukti efektif sebagai hepatoprotektor tetapi studi lebih lanjut diperlukan untuk menarik kesimpulan akhir.
\end{abstract}

Kata kunci: minuman berenergi, Artemisia vulqaris L., hepatopotektor 


\section{Pendahuluan}

Minuman berenergi digunakan masyarakat luas untuk menstimulasi sistem metabolik dan sistem saraf pusat saat belajar, berolahraga, atau mengemudi jarak jauh [1]. Minuman berenergi mengandung kafein, gula sederhana (glukosa, fruktosa), maltodekstrin, asam amino (taurin, karnitin, kreatin), glucuronolactone, dan vitamin B kompleks (niasin, asam pantotenat, piridoksin, riboflavin, inositol, dan kobalamin) [2,3]. Niasin dan derivat niasin lainnya penting dalam metabolisme sel. Namun, kandungan niasin yang melebihi angka kecukupan gizi dalam minuman berenergi yang dikonsumsi terus-menerus memiliki hasil metabolik yang bersifat agen stres oksidatif dan merusak hati. Hati menjadi organ pertama yang berhadapan dengan berbagai xenobiotik yang diingesti tubuh seperti sari-sari makanan, vitamin, logam, obat-obatan, dan zat toksik yang berasal dari lingkungan [4].

Niasin dalam dosis tinggi memiliki mekanisme hepatotoksik berupa gangguan pada mitokondria yang mengakibatkan struktur mitokondria memburuk sehingga menyebabkan apoptosis, nekrosis, infiltrasi sel radang yang bermanifestasi kenaikan enzim aminotransferase ringan sampai sedang dan perubahan histopatologi sel-sel hati yang dikaitkan dengan keadaan klinis seperti acute liver injury parah [5-7]. Penelitian tentang scoparone menyebutkan bahwa scoparone memiliki efek hepatoprotektif dalam melawan kerusakan hati pada tikus [8]. Selain itu scoparone juga memiliki sifat dopaminergik [9] sehingga mampu menunjang potensi dari minuman berenergi. Scoparone adalah salah satu turunan dari kumarin yang merupakan metabolit mayor pada tanaman Artemisia $s p$. [10] termasuk A. Vulgaris L. sehingga diharapkan ekstrak $A$. Vulgaris L. mampu menangkal efek stres oksidatif niasin.

Belum ada penelitian tentang $A$. vulgaris L. yang menunjukkan adanya aktivitas hepatoprotektor terhadap induksi niasin. Oleh karena itu, peneliti ingin mengetahui efektivitas ekstrak $A$. vulgaris $L$. sebagai hepatoprotektor pada sel-sel hati tikus yang diinduksi niasin.

\section{Metode Penelitian}

Jenis penelitian ini adalah experimental laboratories dengan rancangan randomized post test only control group. Penelitian ini menggunakan 25 tikus wistar jantan berumur 23 bulan dengan berat 100-200 gram yang telah mendapatkan izin kelayakan etik penelitian dari Komisi Etik Penelitian Fakultas Kedokteran Universitas Jember.

Hewan coba dibagi menjadi lima kelompok penelitian, yaitu kelompok tanpa perlakuan $(\mathrm{KN})$; kelompok kontrol dengan kafein $1,8 \mathrm{mg} / 200 \mathrm{gram}$ BB dan niasin $32,4 \mathrm{mg} / 200$ gram BB (K-); kelompok kontrol dengan kafein $1,8 \mathrm{mg} / 200$ gram BB, niasin $32,4 \mathrm{mg} / 200$ gram $\mathrm{BB}$, dan scoparone $3,5 \mathrm{mg} / 200$ gram BB $(\mathrm{K}+)$; kelompok perlakuan dengan kafein $1,8 \mathrm{mg} / 200$ gram BB, niasin 32,4 mg/ 200 gram BB, dan ekstrak $A$. Vulgaris $L .5 \mathrm{mg} / 200$ gram BB (P1); kelompok perlakuan dengan kafein $1,8 \mathrm{mg} / 200$ gram BB, niasin $32,4 \mathrm{mg} / 200$ gram BB, dan ekstrak A. Vulgaris L. $10 \mathrm{mg} / 200$ gram BB (P2) yang diadaptasi selama tujuh hari sebelum diberi perlakuan selama 28 hari.

Sebelum dilakukan uji perlakuan, peneliti melakukan uji pendahuluan untuk menentukan dosis niasin dan kafein yang akan diberikan. Tumbuhan $A$. vulgaris $L$. didapatkan dari Kebun Raya Purwodadi Pasuruan. Proses ekstraksi $A$. vulgaris L. menggunakan metode maserasi dengan pelarut etanol $96 \%$. Data hasil pengamatan secara histopatologi diambil dengan mengamati perubahan inti sel, sitoplasma, dan sel secara keseluruhan yang telah diwarnai menggunakan pewarnaan Hematoksilin Eosin (H.E). Untuk membedakan tingkat kerusakan sel hati antar kelompok, peneliti mengklasifikasikan sesuai metode Dewi (2006) yang dimodifikasi, yaitu:

(0) $=$ sel-sel hati normal (tidak terjadi kerusakan sel).

(1) $=$ perubahan struktur ringan $(<25 \%$ sel-sel hati mengalami degenerasi) dan ada aktivitas respon pertahanan sel.

(2) = perubahan struktur ringan $(<25 \%$ sel-sel hati mengalami degenerasi) dan tanpa aktivitas respon pertahanan sel.

(3) = perubahan struktur ringan $(<25 \%$ sel-sel hati mengalami degenerasi) dan ada aktivitas respon pertahanan sel.

(4) $=$ perubahan struktur sedang $(25-50 \%$ selsel hati mengalami degenerasi) dan tanpa aktivitas respon pertahanan sel.

$(5)=$ perubahan struktur berat $(>50 \%$ sel-sel hati mengalami degenerasi dan nekrosis) dan ada aktivitas respon pertahanan sel.

(6) $=$ perubahan struktur berat $(>50 \%$ sel-sel hati mengalami degenerasi dan nekrosis) dan tanpa aktivitas respon pertahanan sel.

Analisis statistik pada penelitian ini menggunakan uji Kruskal Wallis. Selanjutnya dilakukan uji Post Hoc menggunakan Mann 
Whitney untuk menarik kesimpulan antar kelompok yang mempunyai perbedaan. Hasil uji bermakna apabila didapatkan $\mathrm{p}<0,05$ dengan tingkat kepercayaan 95\%.

\section{Hasil Penelitian}

Hasil pengamatan histopatologi hati tikus menunjukkan pada kelompok $\mathrm{KN}, 80 \%$ sampel memiliki gambaran mikroskopis hati yang normal dan $20 \%$ sampel tidak dapat diamati secara mikroskopis karena banyak dijumpai artefak; kelompok K-, 60\% sampel mengalami perubahan struktur sedang dan $40 \%$ sampel mengalami perubahan struktur berat. Tidak terdapat aktivitas respon sel-sel inflamasi pada seluruh sampel yang diperiksa; kelompok $\mathrm{K}+$, seluruh sampel mengalami perubahan struktur sedang disertai aktivitas dominan sel-sel inflamatori; kelompok $\mathrm{P} 1,80 \%$ sampel mengalami perubahan struktur sedang tanpa aktivitas respon sel inflamatori dan $20 \%$ sampel mengalami perubahan struktur sedang disertai aktivitas respon sel inflamatori; dan kelompok P2, $60 \%$ sampel mengalami perubahan struktur sedang tanpa aktivitas respon sel inflamatori, $20 \%$ sampel mengalami perubahan struktur sedang disertai aktivitas respon sel inflamatori, dan $20 \%$ sampel mengalami perubahan struktur ringan disertai aktivitas respon sel inflamatori.

Hasil pengamatan sel-sel hati tikus pada kelompok $\mathrm{KN}, \mathrm{K}-, \mathrm{K}+, \mathrm{P} 1$, dan $\mathrm{P} 2$ perbesaran 400 kali dapat dilihat berturut-turut pada gambar 1 yang menunjukkan hepatosit normal, gambar 2 yang menunjukkan kerusakan hepatosit berat tanpa aktiivitas respon inflamatori, dan gambar 3 , gambar 4 , serta gambar 5 menunjukkan kerusakan hepatosit yang berkurang dibandingkan K- dan ada aktivitas respon inflamatori.

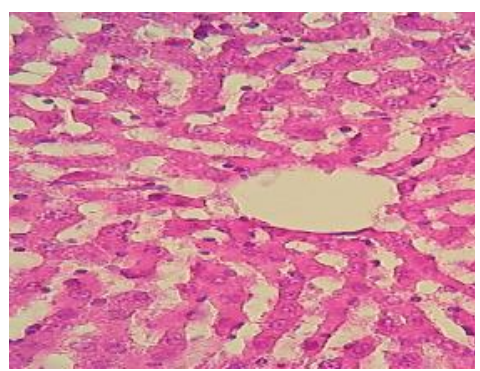

Gambar 1. Foto preparat hati tikus kelompok kontrol normal (perbesaran 400x). Tampak struktur jaringan hati yang tersusun dari lobulus lobulus dengan vena sentral dan hepatocyte plate yang teratur

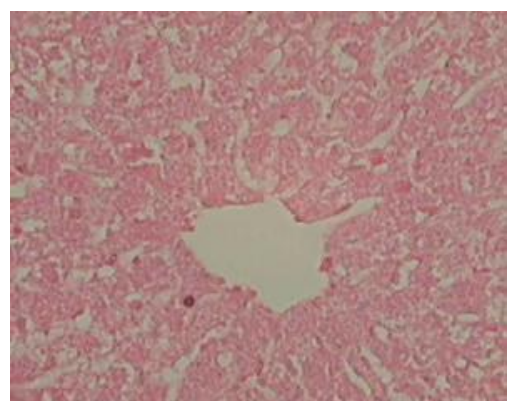

Gambar 2. Foto preparat hati tikus kelompok kontrol negatif (perbesaran 400x). Tampak gambaran nekrosis zonal berupa hepatosit kehilangan inti. Tidak terdapat infiltrasi sel-sel inflamasi pada semua sampel

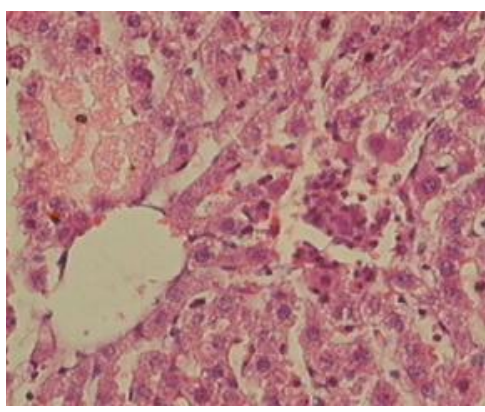

Gambar 3. Foto preparat hati tikus kelompok kontrol positif (perbesaran 400x). Tampak hepatosit masih menunjukkan tanda degenerasi dan beberapa sel kehilangan inti tetapi ada aktivitas respon inflamatori

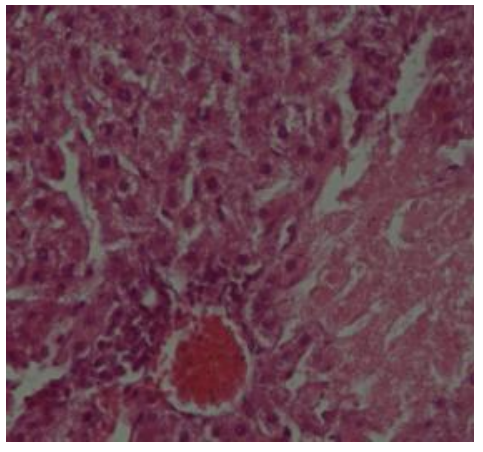

Gambar 4. Foto preparat hati tikus kelompok perlakuan pertama (perbesaran 400x). Terdapat fokus nekrosis berupa sel kehilangan inti di beberapa zona dan tanda degenerasi disertai aktivitas respon inflamatori 


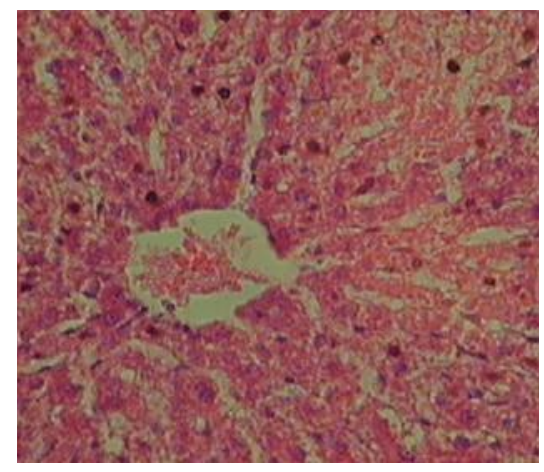

Gambar 5. Foto preparat hati tikus kelompok perlakuan kedua (perbesaran 400x). Terdapat fokus nekrosis berupa sel kehilangan inti dan tanda degenerasi berkurang dan ada aktivitas respon inflamatori

Data diuji dengan uji Kruskal Wallis dan didapatkan $p=0,001$, dilanjutkan uji Mann Whitney yang menunjukkan terdapat perbedaan yang bermakna $(p<0,05)$ antara $K N$ dan semua kelompok; K- dan K+; K+ dan P1. Selain itu, perbedaan tidak bermakna ditunjukkan antara K- dan P1; K- dan P2; K+ dan P2; P1 dan P2.

\section{Pembahasan}

Pada semua kelompok penelitian kecuali kelompok KN, tikus diberi niasin 32,4 $\mathrm{mg} / 200 \mathrm{gram}$ BB dan kafein 1,8 mg/200 gram BB. Pemberian kafein bersama niasin agar bahan yang diberikan dapat menyerupai dengan komponen minuman berenergi yang beredar di masyarakat. Selain itu, satu penelitian tentang kafein juga menyebutkan bahwa dalam dosis tertentu kafein memiliki efek hepatoprotektif [11]. Namun, pemberian dosis efektif kafein ini tetap belum dapat menangkal efek hepatotoksik niasin seperti yang ditunjukkan pada kelompok $\mathrm{K}$-. Berdasarkan hasil penelitian, induksi niasin dosis toksik dan kafein terbukti secara signifikan $(p=0,009)$ merusak sel-sel hati tikus dibandingkan dengan kelompok KN. Normalnya niasin sebanyak $16 \mathrm{mg} /$ hari sudah mencukupi kebutuhan seorang laki-laki dewasa tetapi kandungan niasin pada minuman berenergi sebanyak $20-30 \mathrm{mg} / 250 \mathrm{ml}$ atau $0,45 \mathrm{mg} / \mathrm{kgBB}$. Dosis yang berlebihan ini akan berdampak pada kesehatan. Hasil penelitian tersebut sesuai dengan teori bahwa salah satu hasil metabolik niasin adalah nicotinamide adenine dinucleotide (NAD) yang berpengaruh pada fungsi mitokondria dan mengakibatkan terjadinya apoptosis atau nekrosis yang bermanifestasi pada perubahan gambaran histopatologi sel-sel hati seperti acute liver injury parah $[6,7]$. Penelitian lain juga menyebutkan bahwa pada hasil biopsi hati pada kasus hepatotoksik niasin menunjukkan derajat nekrosis sentrolobular dengan inflamasi hanya sedikit atau ringan [5]. Sifat hepatotoksik niasin memiliki efek langsung yang menyebabkan hepatitis akut atau gabungan dengan kolestatis. Hal ini justru lebih membahayakan karena tubuh tidak sempat atau tidak mampu mengenali zat toksik yang dapat membuat kerusakan berupa kematian sel. Komponen lain dalam minuman berenergi seperti kafein, taurine, gula, dan vitamin B kompleks lainnya dalam jumlah besar tidak berkaitan dengan sifat hepatotoksik $[6,12]$.

Hasil penelitian pada kelompok $\mathrm{K}+$ juga terbukti secara signifikan mencegah kerusakan sel-sel hati tikus dibandingkan dengan kelompok $\mathrm{K}-(\mathrm{p}=0,005)$, meskipun kerusakan masih tidak dapat ditangkal secara total karena gambaran degenerasi masih terlihat dan tampak beberapa sel masih kehilangan inti. Selain itu, aktivitas sel-sel inflamatori tampak dominan dan tersebar yang terdapat pada seluruh sampel kelompok $\mathrm{K}+$, hal ini menunjukkan bahwa ada aktivitas yang membantu mencegah kerusakan atau ada respon ketika hepatosit mengalami kerusakan sehingga kerusakan yang terjadi tidak semakin parah atau meluas. Inflamasi adalah suatu respon protektif yang ditujukan untuk menghilangkan penyebab awal jejas sel serta membuang sel dan jaringan nekrotik sehingga dapat mengalami proses perbaikan, mengganti jaringan yang rusak dengan regenerasi parenkim, atau menyusun kembali tempat terjadinya jejas [13]. Pemberian Scoparone pada dosis 3,5 mg/hari memiliki peran penting dalam mencegah stres oksidatif dengan menjaga membran sel dari kerusakan sel hati [14].

Pada kelompok P1, gambaran sel-sel hati tikus tidak berbeda bermakna dengan kelompok $\mathrm{K}-(p=0,093)$ dan memiliki perbedaan bermakna dengan kelompok $K+(p=0,014)$ menunjukkan pemberian ekstrak $A$. vulgaris $L$. dosis 5 $\mathrm{mg} / 200 \mathrm{gramBB}$ belum mampu sebagai hepatoprotektor sel-sel hati yang diinduksi niasin meskipun terdapat sampel yang telah menunjukkan aktivitas respon sel inflamatori seperti pada kelompok K+. Pada kelompok P2 memiliki efek mengurangi kerusakan sel-sel hati dan telah mengalami upaya perbaikan baik dari tingkat kerusakan degenerasi dan frekuensi nekrosis fokal yang menurun serta gambaran 
aktivitas respon sel inflamasi yang tidak berbeda jauh dengan kelompok $\mathrm{K}+(P=0,23)$. Hasil ini sesuai dengan penelitian sebelumnya bahwa pemberian ekstrak $A$. vulgaris $L$. dapat mengurangi frekuensi hati yang mengalami kerusakan baik nekrosis, degenerasi, maupun hepatosit plate ireguler [15]. Kandungan komponen fenolik $A$. vulgaris $L$. yang diduga bersifat hepatoprotektor adalah scoparone, suatu derivat kumarin yang memiliki aktivitas antioksidan [14].

Penelitian ini telah menunjukkan bahwa konsumsi niasin seperti yang terkandung dalam minuman berenergi dapat berpengaruh pada hati meskipun terdapat senyawa lain yang berpotensi sebagai hepatoprotektor. Selain itu, penelitian ini mengindikasikan bahwa ekstrak $A$. Vulgaris $L$. dapat mengurangi kerusakan sel-sel hati tikus seperti nekrosis zonal yang terjadi pada kelompok K(-) dan memperbaiki frekuensi hepatocyte plate ireguler yang diinduksi niasin namun belum dapat secara signifikan melawan hepatotoksik niasin seperti scoparone murni.

\section{Simpulan dan Saran}

Berdasarkan hasil penelitian dapat disimpulkan bahwa ekstrak $A$. vulgaris $L$. belum terbukti efektif sebagai hepatoprotektor tetapi mempunyai potensi sebagai hepatoprotektor pada sel-sel hati tikus yang diinduksi niasin.

Perlu adanya penelitian lebih lanjut dengan mempertimbangkan variasi dosis ekstrak Artemisia vulgaris yang lebih tinggi pada tikus yang diinduksi niasin dan perlu adanya penelitian lebih lanjut tentang gambaran kerusakan sel hati akibat hepatotoksik niasin dan hepatoprotektor $A$. Vulgaris $L$.

\section{Ucapan Terima Kasih}

Penelitian ini didanai oleh Direktur Penelitian dan Pengabdian Masyarakat, Dirjen DIKTI Kementrian Pendidikan dan Kebudayaan Nasional RI melalui Program Kreativitas Mahasiswa (PKM) bidang penelitian sesuai SK no. 811/E5.3/KPM/2013 tanggal 5 September 2014.

\section{Daftar Pustaka}

[1] Heckman MA, Sherry K, de Mejia EG. Energy drinks: an assessment of their market size, consumer demographics, ingredient profile, functionality, and regulations in the United States. Compr Rev Food Sci Food Saf. 2010; 9: 303-317.
[2] Khayyat L, Jehan S, Maisaa AR and Amina E. Histological, Ultrastructural and Physiological Studies on the Effect of Different Kinds of Energy Drinks on the Liver of wistar Albino Rat. Journal of American Science. 2012; 8(8):688-697

[3] Forbes SC, Candow DG, Little JP, Magnus C, Chilibeck PD. Effect of Red Bull Energy Drink on Repeated Wingate Cycle Performance and Bench-Press Muscle Endurance. International Journal of Sport Nutrition and Exercise Metabolism. 2007; 17: 433-444.

[4] Mescher A. Junqueira's Basic Histology: Text and Atlas. Edisi 12. United States of America: The McGraw-Hill Companies, Inc; 2010.

[5] Summers BB. The Mechanism for Niacin Associated Flushing and Hepatotoxicity. EBM Consulent [Internet]. 2014 [cited 17 September 14]. Available from: http://www.pharmacologyweekly.com/articles /niacin-mechanism-liver-hepatotoxicity.

[6] Apestegui CA, Julliard O, Ciccarelli O, Duc DKHM, Lerut J. Energy Drinks: Another Red Flag for The Liver Allograft. Liver Transplantation. 2011; 17(9): 1117-1118.

[7] Mackay D, Hathcock J, Guarneri E. Niacin: chemical forms, bioavailability, and health effects. Nutrition reviews. 2012; 70(6): 357366.

[8] Zhang A, Sun H, Dou S, Sun W, Wu X, Wang $P$, et al. Metabolomics study on the hepatoprotective effect of scoparone using u Itra-performance liquid chromatography/electrospray ionization quadruple time-of-flight mass spectrometry. Analyst. 2013; 138(1): 353-361.

[9] Yang YJ, Lee HJ, Lee BK, Lim SC, Lee CK, Lee MK. Effects of scoparone on dopamine release in PC12 cells. Fitoterapia. 2010; 81(6): 497-502.

[10] Choi WS, Chang SH, Kim JE, Lee SE. Hypolipidemic effects of scoparone and its coumarin analogues in hyperlipidemia rats induced by high fat diet. Journal of the Korean Society for Applied Biological Chemistry. 2013; 56.6: 647-653.

[11] Costentin CE, Roudot TF, Zafrani ES, Medkour F, Pawlotsky JM, Mallat A, et al. Association of caffeine intake and histological features of chronic hepatitis C. Journal of hepatology. 2011; 54(6): 11231129.

[12] Vivekanandarajah A, Ni S, Waked A. 2011. Acute hepatitis in a woman following 
Rahmawati, et al., Efektivitas Ekstrak Artemisia vulgaris L. sebagai Hepatoprotektor....

excessive ingestion of an energy drink: a case report. Journal of medical case reports. 2011; 5(1): 227.

[13] Kumar V, Cotran RS, Robbins SL. Buku Ajar Patologi Robbins, 7th Edition. Jakarta : EGC. 2012.

[14] Atmaca M, Bilgin HM, Obay BD, Diken H, Kelle M, Kale E. The hepatoprotective effect of coumarin and coumarin derivates on carbon tetrachloride-induced hepatic injury by antioxidative activities in rats. Journal of physiology and biochemistry. 2011; 67(4): 569-576.

[15] Gilani AH, Yaeesh S, Jamal Q, Ghayur MN. Hepatoprotective activity of aqueousmethanol extract of Artemisia vulgaris. Phytotherapy Research. 2005; 19(2): 170172. 